\title{
An Analysis of Credibility of CEO's in an Organisation Linkage with Employee Engagement
}

\author{
Seema Sant ${ }^{1}$ \\ ${ }^{1}$ Vivekan and Education Society, Institute of Management Studies and Research, University of Mumbai, India \\ Correspondence: Seema Sant, Hashu Advani Memorial Complex, Collectors Colony, Chembur, Mumbai, 400074, \\ Maharashtra, India. E-mail: seema.sant@ves.ac.in
}

Received: July 5, 2016

doi:10.5539/ass.v12n10p127
Online Published: September 19, 2016

URL: http://dx.doi.org/10.5539/ass.v12n10p127

\begin{abstract}
The current study examines the credibility of the respective Chief Executive Officer (CEO's) in an organization while linking its impacts with the concurrent facets of employee engagement. The credibility of a Chief Executive Officer (from now on referred to as the CEO) can greatly influence his/her employee's behaviour and perception towards the company's objectives and reputation. A CEO with a credible reputation can help increase the productivity of workforce, the quality and quantity of leads, secure loyal customers, and help in retaining employees. The present study surveyed 186 employees randomly selected from the top 100 companies in India using the questionnaire developed by researcher to measure credibility of CEO linkage with employee engagement. Further the quantitative questionnaires collected from 186 employees were tabulated and analysed in order to study the linkage of the credibility of a CEO in an organization with the employee engagement and its effect on the organization's success. The result shows that the CEO's credibility is positively associated with employee engagement and subsequently affects the organizational reputation and success.
\end{abstract}

Keywords: CEO credibility, employee engagement, organizational success

\section{Introduction}

Engagement at work as conceptualized by Kahn, (1990) describes about an employee who loves his work, who is enthusiastic about his job, who feels a connection to his company, who is fully involved in all the organization's activities is the humble holder of the term 'engaged employee'. They care about the future of the company and are inclined towards putting an extra effort for the company's success. There are generally three factors that drive the employee engagement which are leadership, communication and work life balance (Bedarkar \& Pandita, 2014). Other possible factors that affect the employee engagement are supervisor relationships and work environment (Parsley, 2006; Saks, 2006).

As a rudimentary definition, CEOs are the top executives who play a significant role in directing the strategies and working of their organizations. It has been asserted by Wang et al. (2011) that the pertinent behaviours and leadership style of the CEOs have an amalgamated impact on the pertinent employee engagement within the organization; which is either positive or negative. Park and Berger (2004) in their illuminating work then further claim that the power and leadership exuded by a $C E O$ influences an employee's attitude and performance towards his work.

It is observed that the CEO's credibility inimically comprises of his expertise and trustworthiness that influences the employee engagement that further affects the organization's performance and productivity (O'Keefe, 2002; Bedarkar \& Pandita, 2014). The CEO's credibility is defined in terms of the degree of employee confidence, belief, and acceptance towards the CEO (Park \& Berger, 2004).

However, empirical studies testing how a CEO's credibility factor exactly influences an employee engagement is still scanty and inadequate. The current study analyses the credibility of CEOs in organizations and how it influences the employee engagement. This study focuses on the impact of CEO's demographic variables including leadership, expertise, qualification, proactiveness, trustworthiness and communication on the employee engagement within an organization. 


\section{Literature Review}

\subsection{Employee Engagement}

Goffman (1961) stated that the engagement is the spontaneous involvement of an employee in his work which is also a combination of attention and muscular effort (as cited in Wildermuth \& Pauken, 2008). As defined by Schaufeli et al. (2002), engagement is the achievement of a satisfactory work-related state of mind of an employee that can be represented by alertness, dedication, and involvement in his work. May et al. (2004) listed meaningfulness, safety, and availability as the three psychological conditions of an employee that has a positive connection with the engagement. Robinson et al. (2004) defined the employee engagement as a feeling of positivity by employees towards their organization and its beliefs. The concept of employee engagement was further extended by Saks (2006) into the collaboration of two terms, job engagement, and organization engagement. Fleming and Asplund (2007) pointed out that the employees who are 'engaged' are emotionally and socially connected with their organization and want to see its success by working hard on their mission and purpose.

\subsection{CEO's Credibility Linkage with Employee Engagement}

The study by Saks (2006) established leadership, recognition, work-life balance as the major drivers of employee engagement. He further identified job satisfaction, communication, feeling valued and involved as the factors influencing the employee engagement. All these factors are related to the behaviour of the CEO, i.e., the corporate leader. In the current study, the concept of CEO credibility includes CEO leadership and communication or involvement (O'Keefe, 2002).

\subsubsection{Employee Engagement and CEO's Leadership}

The trust of the employees in the CEO, and furthermore the support from him helps in creating an environment of psychological safety which relates to employee engagement (Lee, 2005). They stated that the leadership style of a CEO is essentially associated with the factors such as job satisfaction, commitment, and motivation that enhance the employee engagement. Griffin et al. (2010) have evaluated the connection between positive leading behaviour and follower's attitude that links with engagement. A few other studies have attempted to provide direct evidence of association between leadership and employee engagement (Metcalfe \& Metcalfe, 2008). As stated by Atwater and Brett (2006), there are three leadership behaviours that directly impact the employee engagement; which are employee development, performance-orientation and consideration.

Metcalfe and Metcalfe (2008) in their prolific work have identified the positive inter-relationship between leadership styles and engagement constructs such as job and organizational commitment, encouragement and work satisfaction. Furthermore, Saks (2006) in his insightful article, "Antecedents and consequences of employee engagement" has observed that the employees who work under the guidance and mentorship of interactive leaders and CEOs exhibit higher levels of engagement. The leadership style of a CEO is positively linked with two aspects; management and mentoring behaviour that can impart confidence, clarification of vision to the employees (Griffin et al., 2010). These aspects with proper direction can be inspirational and result in a team-oriented staff. They also stated that there are specific behaviours of leaders that can influence the engagement; such behaviours are reflected in the employee performance and their understanding of the organizational goals.

\subsubsection{Employee Engagement and CEO's Communication}

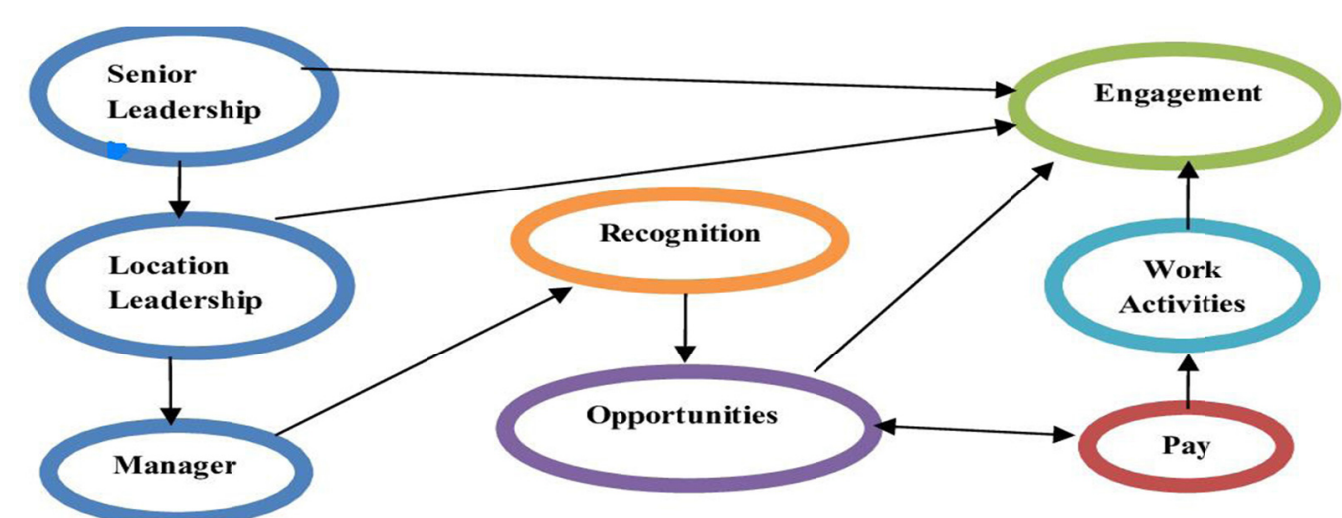

Figure 1. Interrelationships among engagement drivers for DDG companies (Source: Hewitt Associates, 2004) 
Studies by Kahn (1992), Wiley et al. (2010) through their insightful study state that the parameter of communication plays a highly influential role in ensuring the employee engagement. Furthermore, MacLeod and Clarke (2009) have argued that a clear communication channel between superiors or the CEOs and employees facilitates and propels a better understanding among them and also helps the employees in relating their role with the leadership vision. Conversely, they further state that poor communication can limit the progression of employee engagement. Bakker et al. (2011) in their illuminating study have emphasized upon the poignant role of internal communication within an organization as a significant aspect instrumental in order to bring out the effectiveness of employee engagement. It helps in conveying the values of the company to the employees to obtain their support in reaching organizational goals.

\subsection{Relationship between Employee Engagement and the Credibility of CEO in Attaining Organization Success}

Tower Perrin (2006) in his illuminating study titled as, "Ten steps to creating an engaged workforce: key European findings" has stated that the employee engagement is linked to the financial performance of organizations. He further states that employee engagement results in greater employee performance, which further leads to enhanced organizational performance. Gallup (2006) pointed out that a sense of self-efficacy is obtained when an employee is engaged with his work, which creates a positive feeling towards his organization. Kahn (1992) through his poignantly relevant work titled as, "To be fully there: psychological presence at work" observed that engagement may contribute to motivation, creativity and ethical behaviour of the employees with a positive state of well-being. A healthy and positive engagement can attain productivity, customer loyalty and organizations retention and success (Robertson-Smith \& Markwick, 2009).

Men (2012) in his insightful study titled as, "CEO credibility, perceived organizational reputation, and employee engagement" deduced that the CEO's credibility is directly proportional to the reputation of the organization and its employee engagement. She explains that engaging an employee in decision-making, organizational activities and its goals relates to the effectiveness of an organization and builds a more strong relation. Dimopoulos et al. (2010) furthermore through their poignant study titled as, "Cause and Effect in CEO Changes" have examined the relation of the CEO's turnover with the firm's performance and have subsequently observed that in order to enhance the firm's performance; which also states through its numerous arguments that an outsider CEO can be hired instead of a corporate insider. Adams et al. (2005) investigated the impact of powerful CEOs on the performance of the organization and employee engagement. It was observed that the firms with powerful CEOs have both, the worst performances and the best performances.

\subsection{Objective of the Study}

- The objective of the study is to understand does employee engagement relate to the credibility of the CEO of the company

- To understand the relation between Credibility of CEOs, their employee engagement and its overall effect on organisational performance

\subsection{Hypothesis}

$\mathrm{H}_{\mathrm{O}} 1$ : There is no significant relationship between the CEO's skills and employee engagement

$\mathrm{H}_{\mathrm{A}} 1$ : There is significant relationship between the CEO's skills and employee engagement

Hypothesis 2:

$\mathrm{H}_{\mathrm{O}} 2$ : There is no significant relationship between employee engagement and organizational success

$\mathrm{H}_{\mathrm{A}} 2$ : There is significant relationship between employee engagement and organizational success

Hypotheses 3:

$\mathrm{H}_{\mathrm{O}} 3$ : Employee engagement does not influence employee motivation

$\mathrm{H}_{\mathrm{A}} 3$ : Employee engagement influences employee motivation

Hypotheses 4:

$\mathrm{H}_{\mathrm{O}} 4$ : There is no significant relationship between employee's perception of organizational reputation and CEO credibility and employee engagement

$\mathrm{H}_{\mathrm{A}} 4$ : There is significant relationship between employee's perception of organizational reputation and CEO credibility and employee engagement

\section{Methods}

As indicated by Johnson and Christensen (2010), a research paradigm explains the general methodology of the 
research and a research method provides a path with which research is conducted. The current study makes use of Quantitative Research Methods since the method of data collection is in the measurement basis. Malterud (2001) defines that the quantitative researchers will assume the data gains prophecy and clarifications that will create to other places and persons. In this study, a quantitative questionnaire is formulated and distributed among randomly selected employees from top 100 companies in India according to the Business Standard. Likert scale is used in this research for generating the questionnaire. This incumbent five point scale includes the numerous types of codified, bi-polar responses ranging from categories such as "strongly disagree" to "strongly agree." In the due course of the data collection of the research, 186 employees participated in the questionnaire, comprised in the aforementioned top 100 corporate organizations of India. The composition of the participants in the current study consisted of a $45.2 \%$ of the participants who belonged to the age group of 25-34 years. Additionally, it could be deduced that $55.4 \%$ of the participants were men, and subsequently, $44.6 \%$ were women. Lastly, the current study made use of descriptive data analysis and factor analysis which were performed to analyse the data.

\section{Results}

Within this particular section, the researcher undertakes the testing of the, the hypothesis which is carried out with respect to the data collected from the primary participants. The quantitative questionnaires collected from 186 employees are tabulated and analysed in order to study the linkage of the credibility of a CEO in an organization with the employee engagement and its effect on the organization's success; it has been presented in appendix B. A linear regression analysis was applied by using SPSS software to test the hypothesis.

Descriptive Statistics

Table 1. Frequencies distribution for the variable of gender

\begin{tabular}{ccc}
\hline & Frequency & Percent \\
\hline Male & 103 & 55.4 \\
Female & 83 & 44.6 \\
Total & 186 & 100 \\
\hline
\end{tabular}

Table 1 revealed that $55.4 \%$ of the participants surveyed were male as against of $44.6 \%$ of female participants

Table 2. Frequencies distribution age of participants

\begin{tabular}{ccc}
\hline & Frequency & Percent \\
\hline$<18$ years & 18 & 9.7 \\
$18-24$ years & 30 & 16.1 \\
$25-34$ years & 84 & 45.2 \\
35-40 years & 31 & 16.7 \\
40-60 years & 23 & 12.4 \\
Total & 186 & 100 \\
\hline
\end{tabular}

Table 2 revealed that the composition of the participants in the current study consisted of a $45.2 \%$ of the participants who belonged to the age group of $25-34$ years, $16.7 \%$ from $35-40$ whereas $12.4 \%$ from $40-60$ age group.

Table 3. Frequencies distribution of designation of participants

\begin{tabular}{ccc}
\hline & Frequency & Percent \\
\hline Senior manager & 13 & 7 \\
Assistant Manager & 30 & 16.1 \\
General manager & 64 & 34.4 \\
Supervisor & 58 & 31.2 \\
Employee (Subordinate) & 21 & 11.3 \\
Total & 186 & 100 \\
\hline
\end{tabular}


Table 3 describe the designation of the participants among 186 participants senior manager were 13, Assistant manager were 30, General manager were 64, Supervisor were 28 whereas employees were 21 these participants were randomly selected employees from top 100 companies in India had actively participated in the research through questionnaire.

\subsection{Hypotheses 1}

$\mathrm{H}_{\mathrm{O}} 1$ : There is no significant relationship between the CEO's skills and employee engagement

$\mathrm{H}_{\mathrm{A}} 1$ : There is significant relationship between the CEO's skills and employee engagement

Coefficients $^{\mathrm{a}}$

\begin{tabular}{ccccccc}
\hline \multirow{2}{*}{ Model } & \multicolumn{2}{c}{ Unstandardized Coefficients } & Standardized Coefficients & \multirow{2}{*}{ Sig. - } \\
\cline { 2 - 5 } & $\mathrm{B}$ & Std. Error & Beta & & \\
\hline 1 Constant) & 2.134 & .254 & & 8.386 & .000 \\
& Employee engagement & .438 & .070 & .421 & 6.293 & .000 \\
\hline
\end{tabular}

a. Dependent Variable: CEO skills comprising of leadership style and communication

\subsubsection{Inference}

The beta coefficient between the CEO skills and employee engagement was 0.421 and its corresponding $p$ value is $0.000<0.05$. Since the $p$ value is less than 0.05 , we can conclude that there is a significant relationship between CEO's skills and employee engagement. Hence null hypothesis can be rejected and alternate hypothesis can be accepted.

\subsection{Hypothesis 2}

$\mathrm{H}_{\mathrm{O}} 2$ : There is no significant relationship between employee engagement and organizational success

$\mathrm{H}_{\mathrm{A}} 2$ : There is significant relationship between employee engagement and organizational success

\begin{tabular}{ccccccc}
\multicolumn{7}{c}{ Coefficients $^{\mathrm{a}}$} \\
\hline \multirow{2}{*}{ Model } & \multicolumn{2}{c}{ Unstandardized Coefficients } & Standardized Coefficients & \multirow{2}{*}{ Sig. - } \\
\cline { 2 - 5 } & B & Std. Error & Beta & & \\
\hline \multirow{2}{*}{1} & (Constant) & 2.640 & .108 & & 24.514 & .000 \\
& Employee engagement & .236 & .029 & .509 & 8.015 & .000 \\
\hline
\end{tabular}

a. Dependent Variable: Organization success

\subsubsection{Inference:}

The beta coefficient between the organization success and employee engagement was 0.509 and its corresponding $\mathrm{p}$ value is $0.000<0.05$. Since the $\mathrm{p}$ value is less than 0.05 , we can conclude that there is a significant relationship between employee engagement and organization success. Hence null hypothesis can be rejected and alternate hypothesis can be accepted.

\subsection{Hypotheses 3}

$\mathrm{H}_{\mathrm{O}} 3$ : Employee engagement does not influence employee motivation

$\mathrm{H}_{\mathrm{A}} 3$ : Employee engagement influences employee motivation

Coefficients $^{\mathrm{a}}$

\begin{tabular}{cccccrr}
\hline \multirow{2}{*}{ Model } & \multicolumn{2}{c}{ Unstandardized Coefficients } & Standardized Coefficients & \multirow{2}{*}{ S Sig. - } \\
\cline { 3 - 5 } & B & Std. Error & Beta & & \\
\hline \multirow{2}{*}{1} & (Constant) & 3.513 & .512 & & 6.860 & .000 \\
& Employee engagement & .108 & .140 & .057 & $.771 \quad .442$ \\
\hline
\end{tabular}


a. Dependent Variable: Employees who perceive their CEOs as highly trustworthy, credible, competent, and qualified tend to like their company more, express more confidence toward their organization, and have a more favourable assessment of their organization's reputation

\subsubsection{Inference}

The beta coefficient between the CEO skills and employee engagement was 0.057 and its corresponding $\mathrm{p}$ value is $0.442>0.05$. Since the $p$ value is more than 0.05 , we can conclude that there is significant relationship between employee engagement and employee motivation. Hence null hypothesis can be accepted and alternate hypothesis can be rejected.

\subsection{Hypotheses 4}

$\mathrm{H}_{\mathrm{O}} 4$ : There is no significant relationship between employee's perception of organizational reputation and CEO credibility and employee engagement

$\mathrm{H}_{\mathrm{A}} 4$ : There is significant relationship between employee's perception of organizational reputation and CEO credibility and employee engagement

Coefficients $^{\mathrm{a}}$

\begin{tabular}{|c|c|c|c|c|c|c|}
\hline & \multirow{2}{*}{ Model } & \multicolumn{2}{|c|}{ Unstandardized Coefficients } & \multirow{2}{*}{$\frac{\text { Standardized Coefficients }}{\text { Beta }}$} & \multirow{2}{*}{$\mathrm{t}$} & \multirow{2}{*}{ Sig. } \\
\hline & & B & Std. Error & & & \\
\hline \multirow{3}{*}{1} & (Constant) & 1.635 & .108 & & 15.199 & .000 \\
\hline & Employee engagement & .189 & .021 & .407 & 8.871 & .000 \\
\hline & CEO credibility & .329 & .025 & .613 & 13.363 & .000 \\
\hline
\end{tabular}

a. Dependent Variable: Organization success

\subsubsection{Inference}

The beta coefficient between the employee perception of organizational reputation and CEO credibility and employee engagement were 0.407 and 0.613 and its corresponding $p$ value is $0.000<0.05$. Since the $p$ value is less than 0.05 , we can conclude that there is significant relationship between employee perception of organizational reputation and CEO credibility and employee engagement. Hence null hypothesis can be rejected and alternate hypothesis can be accepted.

\section{Discussion}

The underlying discussion section presents the findings of the study in an elaborate manner. The focus of the study primarily was to analyse the credibility of a CEO in an organization linkage with the employee engagement. A detailed analysis of the behaviour of a CEO with his employees and how that influences the employee engagement along with the success and performance of the organization is also evaluated in this study. Further, the study proposed 4 hypotheses and analyses them in depth by conducting quantitative analysis to infer efficient results. The primary data for analysing the effects of CEO's credibility among the employees was collected from 186 employees of top 100 companies in India according to the Business Standard.

\subsection{Characteristics of Employee Engagement}

According to the literature review, Schaufeli et al. (2002) defined engagement as the achievement of a satisfactory work-related state of mind of an employee that can be represented by alertness, dedication, and involvement in his work. Fleming and Asplund (2007) pointed out that the employees who are 'engaged' are emotionally and socially connected with their organization and want to see its success by working hard on their mission and purpose. As per the quantitative analysis, It is observed that majority of about $58.6 \%$ of the participants agreed that employee satisfaction and engagement are related to meaningful business outcomes at a magnitude that is important to many organizations while $20.4 \%$ participants strongly disagree with this statement. The majority of the participants (55\% approximately) agreed that high-quality and fairly priced products help builds employee confidence regarding the future of the company and that employee engagement also affects the mind-set of people. Also, $59.1 \%$ of the participants agreed that engaged employees believe that they can make a difference in the organizations they work for, whereas, $9.7 \%$ of the participants showed a strong disagreement 
with this statement. It is concluded that an engaged employee is a result from job satisfaction and affects the overall company's performance.

\subsection{CEO's Credibility Linkage with Employee Engagement}

The study by Saks (2006) established leadership, recognition, work-life balance as the major drivers of employee engagement. He further identified job satisfaction, communication, feeling valued and involved as the factors influencing the employee engagement. All these factors are related to the behaviour of the CEO, i.e., the corporate leader. According to the analysis, it is observed that $38.7 \%$ of the participants agreed that CEO credibility builds an internal reputation, which in turn boosts employee engagement; of all the participants $25.3 \%$ strongly agree, and $25.3 \%$ are neutral on the above statement. When asked about the CEO's credibility and whether it fosters employee engagement and organizational involvement, as well as enthusiasm and passion for work or not, $54.3 \%$ of the participants agreed, $11 \%$ strongly agreed, $7 \%$ disagreed and 9 strongly disagreed. On the next question, $51.6 \%$ of the participants agreed that a credible CEO who is deemed trustworthy and who demonstrates expertise helps nurture positive employee evaluation of the organization. It can be inferred from the above observations that CEO's credibility is highly associated with employee engagement.

\subsubsection{Impact of CEO's Leadership on Employee Engagement}

As per the literature review, Griffin et al. (2010) stated that the leadership style of a CEO is positively linked with two aspects; management and mentoring behaviour that can impart confidence, clarification of vision to the employees. They also stated that there are specific behaviours of leaders that can influence the engagement; such behaviors are reflected in the employee performance and their understanding of the organizational goals. Saks (2006) has observed that the employees who have interactive leaders and CEOs exhibit higher levels of engagement. As per the quantitative analysis, about $51.1 \%$ of the participants agreed that a conducive work environment is a product of effective leadership, while other employees remained neutral, only $7.5 \%$ disagreed. It can be concluded that the majority of the employees believe that an effective leadership leads to a conducive work environment resulting in better productivity. When asked whether it's important for leaders to show that they value their employees or not, about $60.2 \%$ of the participants agreed that leaders must show that they value their employees. The majority of participants of about $52.7 \%$ of the participants agreed that a conducive work environment is a product of a clearly articulated vision that is communicated by an effective leader. Also, about $40.9 \%$ of the participants expressed that when a CEO is more competent, qualified and possessing more expertise, knowledge and skills, they tend to evaluate organizational reputation more favourably. It was observed that $59.1 \%$ of the participants agreed that effective CEO communication makes CEOs better leaders since leadership is enacted through communication. It can be inferred that an effective leadership quality is not only about proper management but also comprises of a leader's expertise, knowledge, and skills.

\subsubsection{Impact of CEO's Communication on Employee Engagement}

The studies which were undertaken by Kahn (1992) and Wiley et al. (2010) state that communication plays a highly influential role which is instrumental in ensuring employee engagement. MacLeod and Clarke (2009) have stated that a clear communication channel between the superiors or CEOs and also the employees creates a better understanding among them and further helps the employees in relating their role with the leadership vision. Bakker et al. (2011) have stated that internal communication helps in conveying the values of the company to the employees to obtain their support in reaching organizational goals. As per the quantitative analysis, the majority of $41.4 \%$ of the participants agreed that CEO communication quality influences CEO credibility. $68.3 \%$ of the participants agreed that employees perceive a CEO with good communication quality as a leader who is highly credible, dependable, and reliable expert with an advanced level of skills and knowledge. $62.4 \%$ of the participants agreed that employees that work under effective CEO communication tend to identify more with their organization and are more willing to walk the extra mile, express their opinion, and make a difference in the organization. It was evaluated that $38.7 \%$ of the participants think that effective CEO communication empowers them, where $15.6 \%$ strongly agreed, $32.3 \%$ were neutral, and $13.4 \%$ of them disagreed. It can be concluded that effective communication is the key to achieving an effective, transformational, charismatic, authentic, and participative leadership style.

\subsection{Impact of CEO's Credibility on Employee Engagement and Organization's Performance}

Tower Perrin (2006) has stated that employee engagement results in greater employee performance, which further leads to enhanced organizational performance. Men (2012) found that the CEO credibility is directly proportional to the reputation of the organization and its employee engagement. She explains that engaging an employee in decision-making, organizational activities and its goals relates to the effectiveness of an organization and builds a more strong relation. It is observed from the quantitative analysis that majority of $50.5 \%$ 
of the participants agreed that effective CEO communication efforts create an empowered workforce that is happier and more committed to the organization, which eventually contributes to the organizational performance. $49.5 \%$ of the participants agreed that employee perception of organizational reputation fully mediates the positive relationship between CEO credibility and employee engagement; where $14 \%$ of the employees strongly agreed with this statement, $16 \%$ of them were neutral, and $20 \%$ disagreed. The majority of $44.6 \%$ of the participants agreed that employees who perceive their CEOs as highly trustworthy, credible, competent, and qualified tend to like their company more, express more confidence in their organization, and have a more favourable assessment of their organization's reputation. It can be concluded that a CEO with good credibility motivates employees, and such employees tend to have a higher level of engagement, dedication, absorption, and loyalty to their organization.

\section{Conclusion}

A CEO is a company's spokesperson having the administrative and managerial authority of the organization. All the aspects of a company's performance depend on the strategic decision-making and credibility of a CEO. Some of the famous CEOs such as Mark Zuckerberg and Larry Page have imprinted their values on their reputed organizations of Face book and Google respectively (... and so have the ones who have lost their credibility and failed the organisations along with them, Enron, Lehman to name a few ...) In order to achieve this level of success, it is essential to keep the employees 'engaged'. The previous studies described in this paper have indicated that CEOs credibility for being a corporate leader affects the employee engagement with the organization. The current studies have explored how the corporate leadership and the internal communication influence the effectiveness of employees and the organization's performance by linking it with CEO's credibility in the first hypothesis. The quantitative questionnaire used for this paper was formulated and distributed among randomly selected employees from top 100 companies in India showed that CEO's credibility is positively associated with employee engagement and influences the attitude of employees towards organizational reputation and success.

\section{References}

Adams, R., Almeida, H., \& Ferreira, D. (2005). Powerful CEOs and Their Impact on Corporate Performance. Rev. Financ. Stud., 18(4), 1403-1432. http://dx.doi.org/10.1093/rfs/hhi030

Alban-Metcalfe, J., \& Alimo-Metcalfe, B. (2008). Development of a private sector version of the (Engaging) Transformational Leadership Questionnaire. Leadership \& Organization Development Journal, 28(2), 104-121. http://dx.doi.org/10.1108/01437730710726813

Atwater, L. E., \& Brett, J. F. (2006). 360-degree feedback to leaders. Group and Organization Management, 31(5), 578-600. http://dx.doi.org/10.1177/1059601106286887

Bakker, A. B., Hakanen, J. J., Demerouti, E., \& Xanthopoulou, D. (2007). Job resources boost work engagement, particularly when job demands are high. Journal of Psychology, 99(2), 274-84. http://dx.doi.org/10.1037/ 0022-0663.99.2.274

Bedarkar, M., \& Pandita, D. (2014). A Study on the Drivers of Employee Engagement Impacting Employee Performance. Procedia-Social And Behavioural Sciences, 133, 106-115. http://dx.doi.org/10.1016/j.sbspro. 2014.04.174

Dimopoulos, T., \& Wagner, H. Cause and Effect in CEO Changes. SSRN Electronic Journal. http://dx.doi.org/10.2139/ssrn.1640498

Flemming, J. H., \& Asplund, J. (2007). Where employee engagement happens. The Gallup Management Journal. Retrieved from http:/gmj.gallup.com/content/102496/where-Employee-Engagement-Happens.aspx.

Gallup. (2006). Gallup study: engaged employees inspire company innovation: national survey finds that passionate workers are most likely to drive organisations forward. The Gallup Management Journal. http://gmj.gallup.com/content/24880/GallupStudyEngagedEmployeesInspireCompany.aspx

Goffman, E. (1961). Encounters. Penguine University Books. Harmondsworth.

Griffin, M. A., Parker, S. K., \& Mason, C. M. (2010). Leader vision and the development of adaptive and proactive performance: a longitudinal study. Journal of Applied Psychology, 95(1), 174-182. http://dx.doi.org/10.1037/a0017263

Hewitt Associates. (2004). Employee engagement higher at double digit growth companies. Retrieved May 4, 2015, from http://www.mckpeople.com.au/SiteMedia/w3svc161/Uploads/Documents/016fc140-895a-41bf90df-9ddb28f4bdab.pdf 
Johnson, B., \& Christensen, L. B. (2010). Educational Research: Quantitative, Qualitative, and Mixed Approaches. London: SAGE Publications.

Kahn, W. A. (1992). To be fully there: psychological presence at work. Human Relations, 45(4), 321-349. http://dx.doi.org/10.1177/001872679204500402

Lee, J. (2005). Effects of leadership and leader-member exchange on commitment. Leadership \& Organization Development Journal, 26(8), 655-672. http://dx.doi.org/10.1108/01437730510633728

MacLeod, D., \& Clarke, N. (2009). The MacLeod Review - Engaging for Success: Enhancing Performance though Employee Engagement. Department for Business Innovation and Skills. London, Crown Copyright.

Malterud, K. (2001). Qualitative research: Standards, challenges and guidelines (pp. 483-488). UK, The Lancet. http://dx.doi.org/10.1016/s0140-6736(01)05627-6

May, D. R., Gilson, R. L., \& Harter, L. M. (2004). The psychological conditions of meaningfulness, safety and availability and the engagement of the human spirit at work. Journal of Occupational \& Organizational Psychology, 77, 11-37. http://dx.doi.org/10.1348/096317904322915892

Men, L. (2012). CEO credibility, perceived organizational reputation, and employee engagement. Public Relations Review, 38(1), 171-173. http://dx.doi.org/10.1016/j.pubrev.2011.12.011

O'Keefe, D. J. (2002). Persuasion: Theory and research (2nd ed.). Sage Publications, Inc.

Park, D., \& Berger, B. K. (2004). The presentation of CEOs in the press, 1990-2000: Increasing salience, positive valence, and a focus on competency and personal dimensions of image. Journal of Public Relations Research, 16, 93-125. http://dx.doi.org/10.1207/s1532754xjprr1601_4

Parsley, A. (2006, Spring). Road map for employee engagement. Management Services, 10-11.

Robertson-Smith, G., \& Markwick, C. (2009). Employee Engagement: A Review of Current Thinking. Institute for Employment Studies.

Robinson, D., Perryman, S., \& Hayday, S. (2004). The drivers of employee engagement. Institute for Employment Studies, Brighton.

Saks, A. M. (2006). Antecedents and consequences of employee engagement. Journal of Managerial Psychology, 21, 600-618. http://dx.doi.org/10.1108/02683940610690169

Shaufeli, W. B., Salanova, M., Gonzalez, R. V., \& Bakker, A. B. (2002). The measurement of engagementand burnout: a two sample confirmatory factor analytic approach. Journal of Happiness Studies, 3, 71-92. http://dx.doi.org/10.1023/A:1015630930326

Tower, P. (2006). Ten steps to creating an engaged workforce: Key European findings. Towers Perin HR Services.

Wang, H., Tsui, A. S., \& Xin, K. R. (2011). Leadership behaviours, organizational performance and employee's attitude. Leadersh. Q., 22, 92-105. http://dx.doi.org/10.1016/j.leaqua.2010.12.009

Wildermuth, C., \& Pauken, P. D. (2008). A Perfect math: decoding employee engagement-Part I: Engaging cultures and leaders. Industrial and Commercial Training. Emerald Group Publishing Limited, 40(3), 122-128. http://dx.doi.org/10.1108/00197850810868603

Wiley, J. W., Kowske, B. J., \& Herman, A. E. (2010). Developing and validating a global model of employee engagement. In S. L. Albrecht (Ed.), Handbook of Employee Engagement: Perspectives, Issues, Research and Practice. Edward Elgar. Cheltenham. http://dx.doi.org/10.4337/9781849806374.00039

\section{Copyrights}

Copyright for this article is retained by the author(s), with first publication rights granted to the journal.

This is an open-access article distributed under the terms and conditions of the Creative Commons Attribution license (http://creativecommons.org/licenses/by/4.0/). 